Economics Development Analysis Journal 7(2)(2018) Enomics Development Analysis Journal

\title{
Analisis Tipologi Potensi Pariwisata di Provinsi Jawa Tengah
}

\author{
Lutfie Juliarizka Mustofa ${ }^{1 凶}$, Titik Haryati $^{2}$
}

Jurusan Ekonomi Pembangunan, Fakultas Ekonomi, Universitas Negeri Semarang

\begin{tabular}{l}
\hline Info Artikel \\
\hline Sejarah Artikel: \\
Diterima Januari 2018 \\
Disetujui Maret 2018 \\
Dipublikasikan Mei 2018
\end{tabular}

Keywords:

Tourism, Typology,

Development, Typology

Klassen, Overlay

\begin{abstract}
Abstrak
Pariwisata merupakan salah satu bagian yang penting dari sebuah Daerah/Provinsi. Selain sebagai tempat rekreasi, pariwisata juga penting dalam 3 aspek, dari aspek ekonomi sebagai sumber pendapatan dan pajak, dari aspek sosial penciptaan lapangan kerja serta dari aspek budaya kita dapat memperkenalkan budaya kepada wistawan. Metode yang digunakan yaitu Klassen Typologi, LQ, MRP, dan Overlay. Dengan mengambil wilayah studi seluruh kabupaten/kota di Provinsi Jawa Tengah. hasil analisis dengan beberapa metode tersebut didapat hasil bahwa kabupaten Banjarnegara, Kab. Semarang, Kota Magelang, dan Kebumen merupakan kabupaten dengan pariwisata unggulan. untuk jenis wisata Alam yaitu Banjarnegara, Banyumas, Klaten, Wonosobo. Sedangkan Banjarnegara, Kab. Semarang, Kota Magelang, dan Kota Surakarta merupakan kabupaten/kota unggulan untuk jenis wisata buatan. Wisata bahari yang menjadi unggulan yaitu Brebes, Demak, Kebumen, Purworejo, Rembang, dan Kota Pekalongan. Wisata religi yang menjadi unggulan adalah Jepara dan Kab. Semarang. Kebumen, Kabupaten Magelang, Sragen, dan Wonosobo merupakan kabupaten dengan keunggulan jenis wisata kesehatannya. Wisata sejarah dan wisata budaya tidak ada yang unggul di semua kabupaten/kota. Kesimpulannya masih banyak kabupaten/kota yang belum potensial untuk itu pemerintah dapat mengembangkan sektor pariwisatanya disesuaikan dengan jenis wisatanya yang mempunyai keunggulan atau potensial untuk dikembangkan.
\end{abstract}

\begin{abstract}
Tourism is one important part of a Regional / Provincial. Aside from being a place for recreation, tourism is also important in three aspects, economic aspects as a source of income and tax aspects of employment creation and social aspects of our culture can introduce the culture to wistawan. The method used is KlassenTypologi,LQ, $M R P$, and Overlay. By taking the entire study area districts / cities in Central Java province. the analysis results with some of these methods result is thatdistrict, Banjarnegara Kab. Semarang, Magelang, and Kebumen district is featured tourism. for this type of travel, namely Alam Banjarnegara, Banyumas, Klaten, Wonosobo. While Banjarnegara, Kab. Semarang, Magelang and Surakarta is a regency / city featured on the type of artificial travel. Marine tourism is seeded Brebes, Demak, Kebumen, Purworejo, Rembang, and Pekalongan. Religious tourism is the flagship and Kab Jepara. Semarang. Kebumen, Magelang, Sragen and Wonosobo is the district with the advantages of the type of travel health. The historical and cultural attractions nothing superior in all districts / cities. In conclusion there are many districts / cities who have the potential for the government to develop the tourism sector adapted to the type of tourism that has an advantage or potential for development.
\end{abstract}




\section{PENDAHULUAN}

Pariwisata merupakan salah satu bagian yang penting dari sebuah Daerah/Provinsi. Selain sebagai tempat rekreasi, pariwisata juga penting dalam 3 aspek, dari aspek ekonomi sebagai sumber pendapatan dan pajak, dari aspek sosial penciptaan lapangan kerja serta dari aspek budaya kita dapat memperkenalkan budaya kepada wisatawan. Wisata yang unik dan menarik akan menjadi identitas suatu daerah sehingga akan lebih dikenal oleh masyarakat. Jero Wacik dalam sambutannya sebagai Menteri Kebudayaan dan Pariwisata dalam Warpani, (2007) mengemukakan bahwa, "Pariwisata adalah sektor yang mendapat perhatian penting, karena pariwisata dapat memulihkan ekonomi secara cepat dan merata, khususnya perekonomian masayarakat lokal. Untuk itu pariwisata perlu didorong pembangunannya lebih terarah dan terencana".

Pariwisata di Indonesia apabila mampu dikelola dengan baik akan menjadi aset Indonesia. Keberagaman pariwisata Indonesia dapat dijadikan salah satu penopang perekonomian. Selain itu berkembangnya sektor pariwisata di suatu wilayah juga dapat memicu perkembangan padasektor-sektor lainnya, seperti bidang pertanian, peternakan, perkebunan, kerajinan dan lainnya. Hal ini tidaklah berlebihan mengingat potensi pariwisata yang dimiliki oleh indonesia cukup besar, bahkan banyak diantaranya yang belum dimanfaatkan secara optimal.

Salah satu Provinsi yang memiliki keberagaman pariwisata yaitu Provinsi Jawa Tengah, letaknya cukup strategis karena berada di daratan padat di Pulau Jawa, diapit oleh dua Provinsi besar Jawa Barat dan Jawa Timur, satu Daerah Istimewa Yogyakarta, dan Laut Jawa di sebelah utara. Luas wilayahnya $34.548 \mathrm{~km}^{2}$, atau sekitar 28,94\% dari luas pulau (termasuk Kepulauan Karimunjawa). Dengan topografi seperti diatas tidak heran jika Jawa Tengah memiliki potensi wisata yang sangat beragam jenis. Namun belum semua potensi wisata di Jawa Tengah dikelola dengan baik, hal tersebut dapat terlihat dari pendapatan sektor pariwisata, Jawa Tengah merupakan urutan ketiga dari bawah, urutan tertinggi ditempati oleh DKI Jakarta, kedua Jawa Barat, selanjutnya ditempati oleh Jawa Timur, Daerah Istimewa Yogyakarta dan terakhir Banten (Tabel 1).

Tabel 1

Pendapatan Sektor Pariwisata 6 Provinsi Pulau Jawa Tahun 2011-2015 (dalam Juta)

\begin{tabular}{llllll}
\hline Provinsi & 2011 & 2012 & 2013 & 2014 & 2015 \\
\hline DKI Jakarta & 2.345 .221 & 2.535 .293 & 3.129 .712 & 3.912 .471 & 4.271 .820 \\
Jawa Barat & 365.689 & 417.930 & 419.184 & 420.242 & 442.231 \\
Banten & 66.826 & 63.518 & 68.952 & 65.458 & 65.169 \\
JawaTengah & 130.876 & 182.513 & 220.025 & 236.813 & 261.702 \\
DIY & 106.215 & 153.174 & 188.839 & 241.955 & 286.993 \\
Jawa Timur & 269.430 & 298.619 & 323.854 & 361.983 & 398.210 \\
\hline
\end{tabular}

Meskipun pendapatan sektor pariwisata Jawa Tengah lebih sedikit dibanding tiga provinsi lainnya, tetapi jumlah objek wisata yang dimiliki Provinsi Jawa tengah adalah paling banyak dibandingkan lima propinsi lainnya yang ada di pulai Jawa (tabel 2). Hal tersebut tentunya akan berimbas pada penurunan jumlah Pendapatan Asli Daerah (PAD) melalui retribusi objek wisata. Berkembangnya sektor pariwisata di Provinsi Jawa Tengah, maka secara tidak langsung akan berdampak pada pembangunan sarana dan prasarana di Provinsi Jawa Tengah, oleh karena itu, salah satu upaya yang dapat dilakukan guna meningkatkan potensi pariwisata di Jawa Tengah adalah dengan melakukan konsep pengembangan pariwisata Jawa Tengah tetapi dengan tetap memperhatikan aspek 
konservasi seperti pengembangan wisata alam, budaya, religi, sejarah dan lain sebagainya, konsep pengembangan yang dilakukan yaitu dengan cara mengklasifikasikan kabupaten/kota manakah yang menjadi unggulan dalam pariwisata serta menggali potensi jenis wisata yang ada di Provinsi Jawa Tengah sehingga nantinya akan mudah melakukan pengembangan pariwisata.

Tabel 2. Jumlah Objek Wisata 6 Provinsi Pulau Jawa Tahun 2011-2015

\begin{tabular}{cc}
\hline Provinsi & $\begin{array}{c}\text { Jumlah } \\
\text { Objek } \\
\text { Wisata }\end{array}$ \\
\hline DKI Jakarta & 32 \\
Jawa Barat & 218 \\
Banten & 210 \\
JawaTengah & 317 \\
DIY & 115 \\
Jawa Timur & 235 \\
\hline
\end{tabular}

Sumber: Pusdatin Kementerian Pariwisata Indonesia, 2011-2015

\section{METODE PENELITIAN}

Penelitian ini merupakan penelitian deskriptif kuantitatif, yaitu suatu peneltian yang berfungsi untuk mendeskripsikan atau memberi gambaran terhadap situasi-situasi atau kejadiankejadian objek yang diteliti. Analisis deskriptif adalah suatu kegiatan menganalisis, menginterpretasikan data dengan mengambil kesimpulan dari data-data dalam bentuk angka yang sudah ada ke dalam bentuk tulisan atau kata-kata (Arikunto, 2006:72).

Objek penelitian ini yaitu di provinsi Jawa Tengah yang terdiri dari 35 Kabupaten/Kota. Data yang digunakan dalam penelitian ini adalah data sekunder yang diperoleh dari Dinas Pariwisata dan Kebudayaan Provinsi Jawa Tengah dan Kementerian Pariwisata dan Ekonomi Kreatif Republik Indonesia periode pengamatan tahun 2011-2015. Data yang digunakan seperti : Pendapatan Sektor Pariwisata Provinsi Jawa Tengah tahun 20112015, Pendapatan Sektor Pariwisata Kabupaten/Kota di Provinsi Jawa Tengah Tahun 2011-2015, dan Pendapatan Asli Daerah
Provinsi Jawa Tengah tahun 2011-2015 dengan alat analisis yang akan digunakan adalah sebagai berikut:

Menurut Imelia, E (2006), analisis Tipologi Klassen digunakan untuk melihat gambaran tentang pola dan struktur pertumbuhan masing-masing sektor ekonomi. Dalam penelitian ini indikator utama yang digunakan yaitu, Pertumbuhan Sektor Pariwisata dan Kontribusi Sektor Pariwisata, dengan menentukan rata rata pertumbuhan sektor pariwisata sebagai sumbu vertikal dan rata-rata kontribusi sektor pariwisata sebagai sumbu horizontal.

Tabel 3. Klasifikasi menurut Tipologi

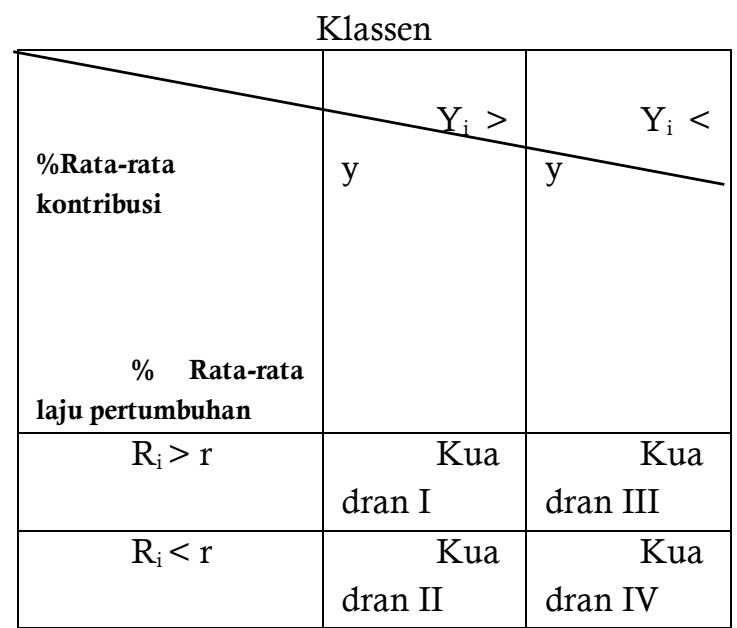

Sumber: Imelia E, 2006

Dimana:

$\mathrm{Y}_{\mathrm{i}} \quad$ : Pertumbuhan sektor pariwisata di kab/kota i

$\mathrm{R}_{\mathrm{i}} \quad$ : kontribusi sektor pariwisata di $\mathrm{kab} /$ kota i

y : pertumbuhan sektor pariwisata Provinsi Jawa Tengah

r : kontribusi sektor pariwisata Provinsi Jawa Tengah

Kontribusi dapat dinyatakan dalam rumus: kontribusi $=\frac{\text { pendapatan sektor pariwisata }}{\text { total PAD }} \times 100 \%$

Sedangkan untuk presentase laju pertumbuhan dapat dinyatakan dengan rumus: Laju Pertumbuhan $=\frac{(E i, t-E i, t-1)}{E i, j, t-1} \times 100 \% \mathrm{~K}$ 
Keterangan:

$\mathrm{E}_{\mathrm{i}, \mathrm{t}}$ : Pendapatan sektor pariwisata di Kab/Kota $\mathrm{i}$ pada tahun $\mathrm{t}$

$\mathrm{E}_{\mathrm{i}, \mathrm{t}-1}$ : Pendapatan sektor pariwisata di $\mathrm{Kab} / \mathrm{Kota}$ i pada tahun $\mathrm{t}-1$

Analisis Overlay, analisis ini dimaksudkan untuk menentukan sektor potensial berdasarkan penggabungan Metode LQ dan Metode MRP Berdasarkan Basuki dan Gayatri (2009. berikut:

Adapun metode LQ adalah sebagai

$$
L Q=\frac{E i 1 / E 1}{E i 2 / E 2}
$$

Dimana:

$\mathrm{E}_{\mathrm{i} 1} \quad$ : Pendapatan sektor pariwisata wilayah studi

$\mathrm{E}_{1} \quad$ : PAD wilayah studi

$\mathrm{E}_{\mathrm{i} 2} \quad$ : Pendapatan sektor pariwisata wilayah referensi

$\mathrm{E}_{2} \quad:$ PAD wilayah referensi

Dan untuk metodr MRP dalam penelitian ini menggunakan persamaan rumus $\mathrm{MRP}_{\mathrm{S}}$, yaitu perbandingan antara laju pertumbuhan sektor i wilayah studi dengan laju pertumbuhan sektor i wilayah referensi, dapat dinyatakan dalam rumus berikut:

$$
\mathrm{RP}_{\mathrm{S}}=\frac{\Delta E i 1 / \operatorname{Ei1}(t-1)}{\Delta E i 2 / E i 2(t-1)}
$$

\section{HASIL DAN PEMBAHASAN}

Melalui analisis Tipologi Klassen ini dapat melihat gambaran tentang pola dan struktur pertumbuhan sektor pariwisata pada masingmasing Kabupaten/Kota di Provisi Jawa Tengah. Gambaran tentang pola dan struktur pertumbuhan Kabupaten/Kota ini, dapat dipergunakan untuk memperkirakan prospek pertumbuhan ekonomi daerah pada masa mendatang. Selain itu, hal tersebut juga dapat dipergunakan sebagai bahan pertimbangan dalam menentukan kebijaksanaan pembangunan daerah khususnya sektor pariwisatanya. Untuk Pariwisata Jawa Tengah Terdapat empat Daerah yang berada pada kuadran I, yaitu Kab. Banjarnegara, Kab. Semarang, Kota Magelang, dan Kab. Kebumen. Pada Kuadran II terlihat bahwa terdapat Kab. Karanganyar, Kab. Magelang, Kab. Purbalingga, Kab. Temanggung dan Kab. Wonogiri. Pada Kuadran III terdapat Kab. Banyumas, Kab. Batang, Kab. Blora, Kab. Boyolali, Kab. Brebes, Kab. Grobogan, Kab. Kendal, Kab. Klaten, Kab. Kudus, Kab. Pati, Kab. Pekalongan, Kab. Purworejo, Kab. Rembang, Kab. Wonosobo, Kota Semarang, Kota Surakarta, Kota Tegal, dan Kab. Sragen. Sedangkan untuk kuadran IV terdapat Kab. Cilacap, Kab. Demak, Kab.Pemalang, Kab. Sukoharjo, Kab. Tegal, Kota Pekalongan, Kota Salatiga, Kab. Jepara

\section{Wisata Alam}

Pada Kuadran I terdapat Kab. Banjarnegara, Kab. Banyumas, Kab. Klaten, dan Kab. Wonosobo. Untuk kKuadran II, terdapat Kab. Karanganyar, Kab. Kebumen, Kab. Kendal, dan Kab. Purbalingga. Pada Kuadran III terdapat Kab. Batang, Kab. Cilacap, Kab. Kudus, Kab. Magelang, Kab. Pati, Kab. Purworejo, Kab. Semarang, Kab. Temanggung, dan Kota Semarang. Sedangkan Kuadran IV terdapat Kab. Blora, Kab. Boyolali, Kab. Brebes, Kab. Grobogan, Kab. Jepara, Kab. Pekalongan, Kab. Pemalang, Kab. Rembang, Kab. Sukoharjo, dan Kab. Wonogiri.

\section{Wisata Buatan}

Pada Kuadran I terdapat Kab. Banjarnegara, Kab. Semarang, Kota Magelang, dan Kota Surakarta. Pada Kuadran II terdapat Kab. Magelang, Kab. Pemalang, Kab. Purbalingga, Kab. Temanggung dan Kab. Wonogiri. Pada Kuadran III terdapat Kab. Banyumas, Kab. Batang, Kab. Blora, Kab. Boyolali, Kab. Cilacap, Kab. Grobogan, Kab. Karanganyar, Kab. Kebumen, Kab. Kendal, Kab. Kudus, Kab. Pati, Kab. Pekalongan, Kab. Purworejo, Kab. Sragen, dan Kota Semarang. Pada Kuadran IV terdapat Kab. Brebes, Kab. Demak, Kab. Jepara, Kab. Wonosobo, Kota Pekalongan, Kota Salatiga, dan Kota Tegal.

\section{Wisata Bahari}

Pada Kuadran I terdapat Kab. Brebes, Kab. Demak, Kab. Kebumen, Kab. Purworejo, Kab. Rembang dan Kota Pekalongan. Untuk Kuadran II terdapat Kab. Batang, Kab. Cilacap, Kab. Jepara, Kab. Pemalang, Kab. Tegal dan 
Kota Tegal. Pada Kuadran III terdapat Kab. Pekalongan, Kab. Wonogiri dan Kab. Kendal, Sedangkan pada Kuadran IV terdapat Kab. Pati dan Kota Semarang.

\section{Wisata Religi}

Pada kuadran I terdapat Kab. Jepara dan Kota Semarang, pada Kuadran II terdapat Kab. Demak, Kab. Karanganyar, Kab. Klaten dan Kab. Kudus, untuk Kuadran III terdapat Kab. Banyumas, Kab. Boyolali, Kab. Pati, Kab. Purbalingga, Kab. Semarang, dan Kota Semarang. Sedangkan untuk Kuadran IV terdapat Kab. Cilacap, Kabupaten Grobogan dan Kab. Sukoharjo.

\section{Wisata Sejarah}

Pada kuadran I tidak ada yang menjadi unggulan wisata sejarah. Pada kuadran II hanya ada satu Kabupaten yaitu Kabupaten Magelang, sedangkan pada Kuadran III terdapat Kab. Banyumas, Kab. Klaten, Kab. Kudus, Kab. Pati, Kab. Purbalingga, Kab. Rembang, Kab. Semarang, Kab. Sragen, Kab. Temanggung, Kota Magelang, Kota Pekalongan, Kota Salatiga, Kota Semarang dan Kota Surakarta dan untuk Kuadran IV terdapat Kab. Cilacap, Kab. Jepara, Kab. Karanganyar, Kab. Purworejo dan $\mathrm{Kab}$. Wonogiri.

\section{Wisata Kesehatan}

Menunjukkan bahwa pada kuadran I terdapat Kab. Kebumen, Kab. Magelang, Kab. Sragen, dan Kab. Wonosobo, pada kuadran II terdapat Kab. Brebes dan Kab. Tegal, untuk Kuadran III terdapat Kab. Batang, Kab. Cilacap dan Kab. Kendal sedangkan pada Kuadran IV terdapat Kab. Banyumas dan Kab. Karanganyar.

\section{Wisata Budaya}

Pada Wisata Budaya tidak terdapat satupun $\mathrm{Kab} / \mathrm{Kota}$ yang berada pada kuadran I dan IV. Pada kuadran II terdapat tiga Kab/Kota yaitu Kab. Klaten, Sragen, dan Kota Surakarta. Sedangakan pada Kuadran II hanya terdapat Kota Semarang.

Peta Pengembangan Pariwisata Provinsi Jawa Tengah

Dengan memadukan hasil analisis LQ dan MRPs maka dapat diketahui Kabupaten/Kota di Jawa Tengah yang mempunyai keunggulan kompetitif dan komparatif menunjukkan bahwa terdapat terdapat empat Kabupaten/Kota yang potensial untuk dikembangkan sektor pariwisatanya yaitu Kab. Banjarnegara, Kab. Kebumen, Kab. Semarang dan Kota Magelang.

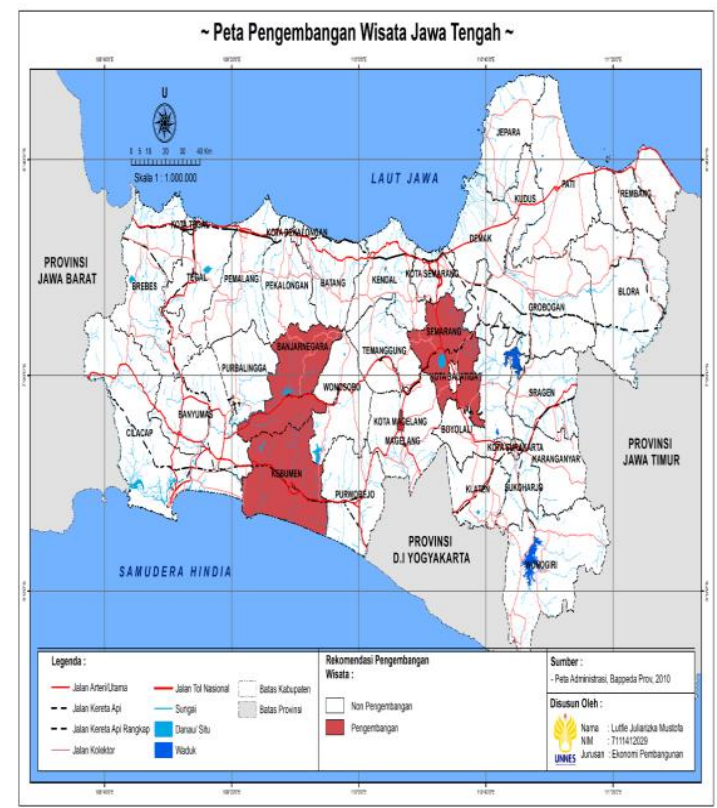

Sedangkan Kabupaten/Kota yang dapat direkomendasikan untuk dapat dilakukan pengembangan pada sektor wisata khusunya wisata alam adalah Kab. Banjarnegara, Kab. Banyumas, Kab. Klaten, dan Kab. Wonosobo.

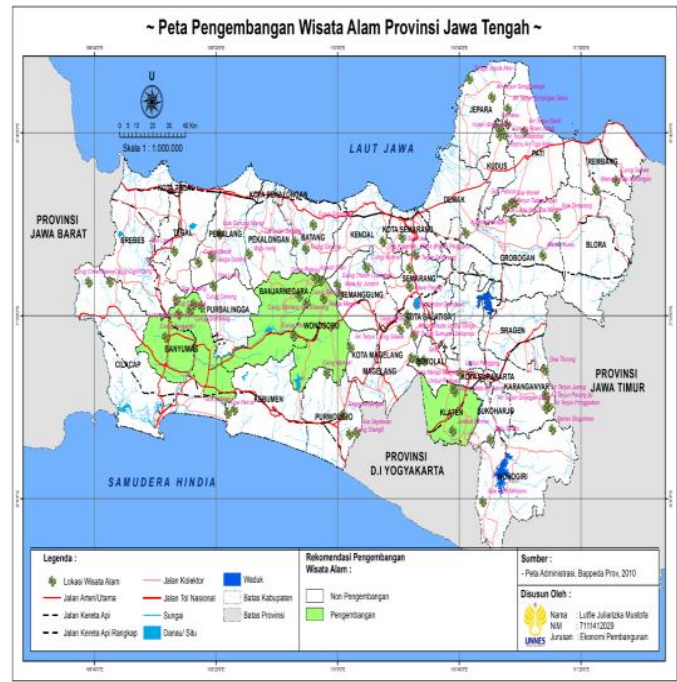

Terdapat empat Kabupaten/Kota yang dapat direkomendasikan untuk dapat dilakukan pengembangan pada sektor wisata khusunya wisata buatan yaitu Kab. Banjarnegara, Kab. Semarang, Kota Magelang, dan Kota Surakarta. 


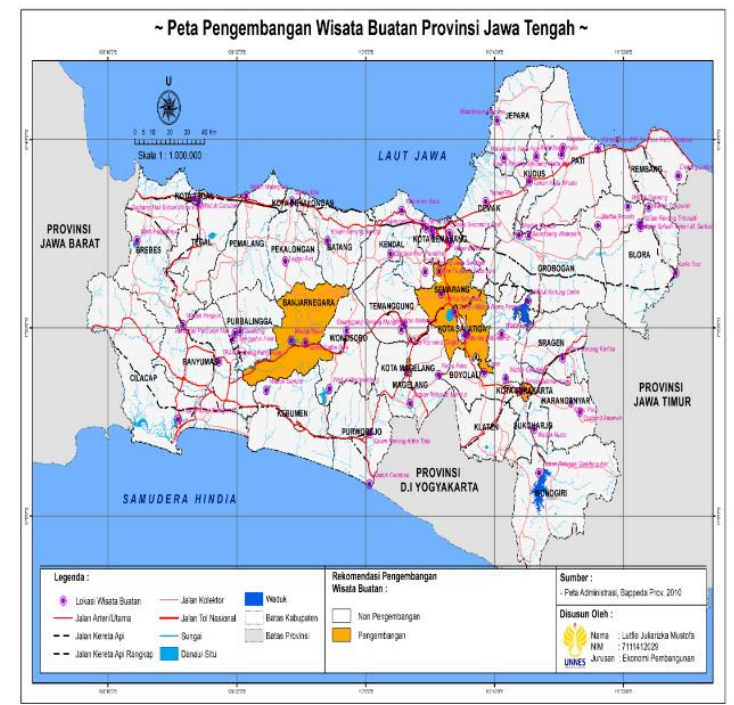

Untuk wisata bahari menunjukkan bahwa terdapat enam Kabupaten/Kota yang dapat direkomendasikan untuk dapat dilakukan pengembangan pada sektor wisata khusunya wisata baharinya yaitu Kab. Brebes, Kab. Demak, Kab, Kebumen, Kab. Purworejo, Kab. Rembang, dan Kota Pekalongan

Kabupaten/Kota yang dapat direkomendasikan untuk dapat dilakukan pengembangan pada sektor wisata khusunya wisata religinya yaitu Kabupaten Jepara dan Kabupaten Semarang.

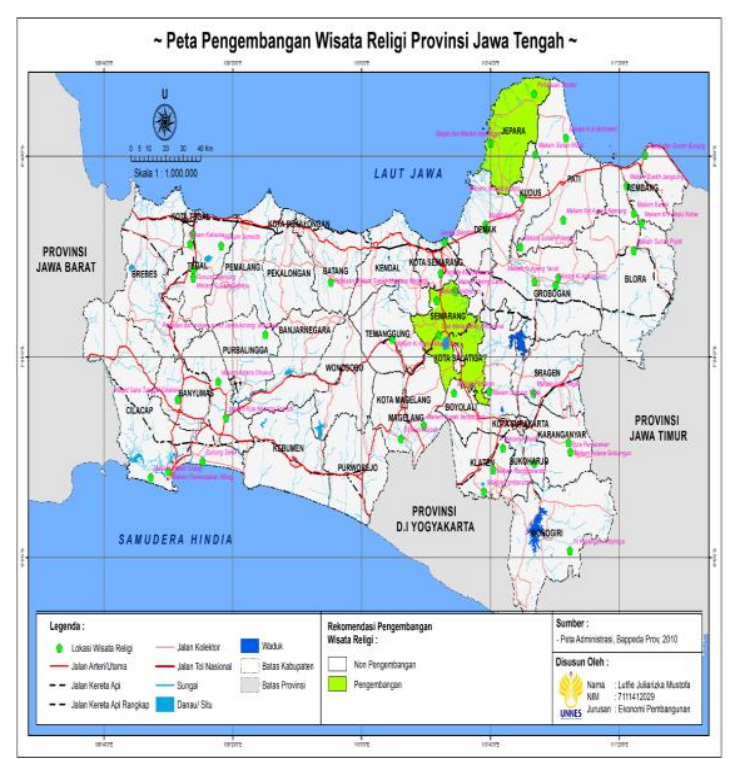

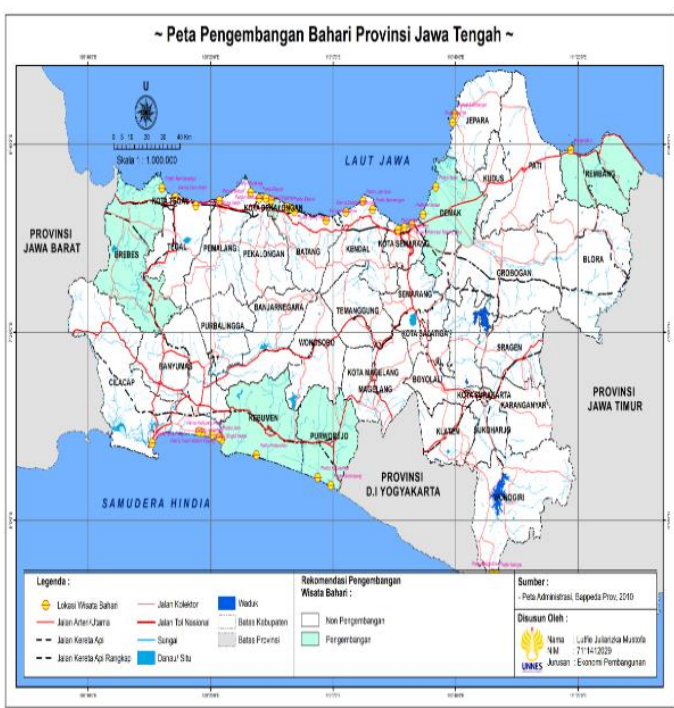

Untuk wisata sejarah tidak terdapat satupun Kabupaten/Kota yang dapat direkomendasikan untuk merencanakan pengembangan wisata sejarah. Hanya ada satu Kabupaten yang wisata sejarahnya mempunyai kontribusi positif yaitu Kabupaten Magelang karena memang kontribusi wisata sejarah Kabupaten magelang mempunyai kontribusi yang sangat besar dan menjadi andalan sumber pendapatan Kabupaten Magelang. Objek Wisata sejarah yang dimiliki Kabupaten magelang sudah terkenal di dunia yaitu Candi Borobudur. Ratarata kontribusi wisata sejarah terhadap PAD selama 2011-2015 adalah 66,33\%. Namun demikian pendapatan dari wisata sejarah Kabupaten Magelang cenderung melambat sehingga nilai rasio pertumbuhannya negatif.

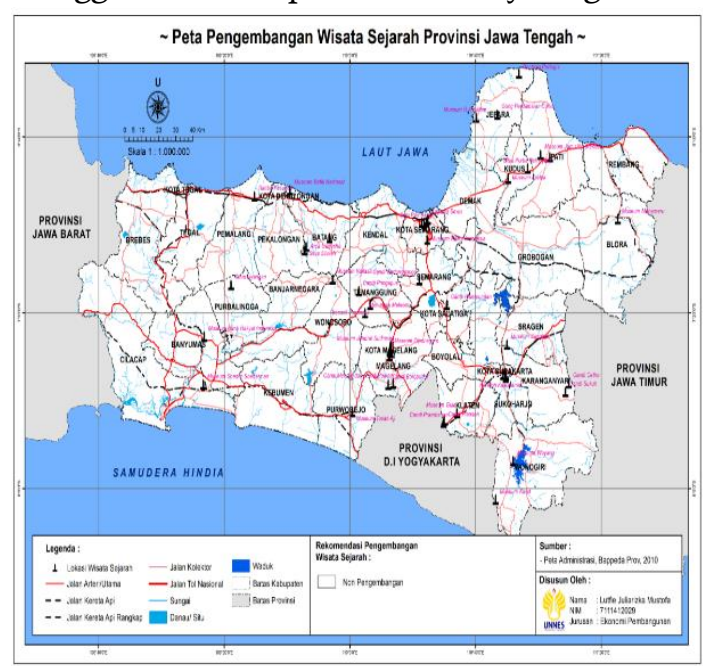


Untuk jenis wisata kesehatan terdapat empat Kabupaten/Kota yang dapat direkomendasikan untuk dapat dilakukan pengembangan yaitu Kab. Kebumen, Kab. Magelang, Kab. Sragen, dan Kab. Wonosobo.

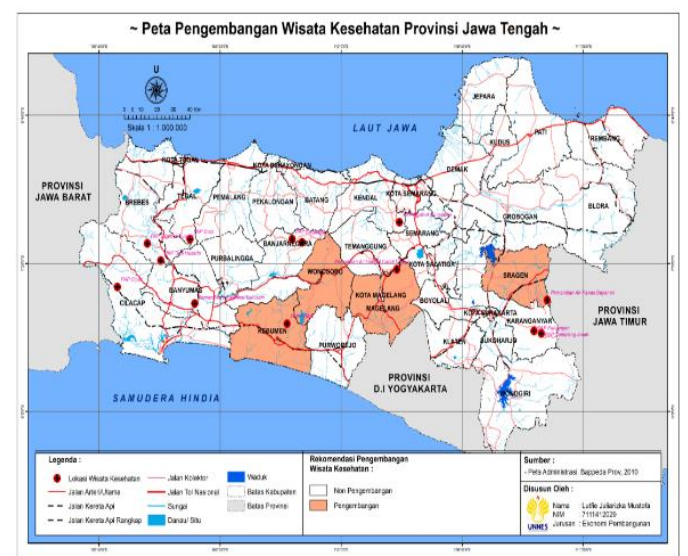

Untuk Wisata budaya menunjukkan bahwa tidak terdapat satupun Kabupaten/Kota yang dapat direkomendasikan untuk dapat dilakukan pengembangan pada wisata budayanya.

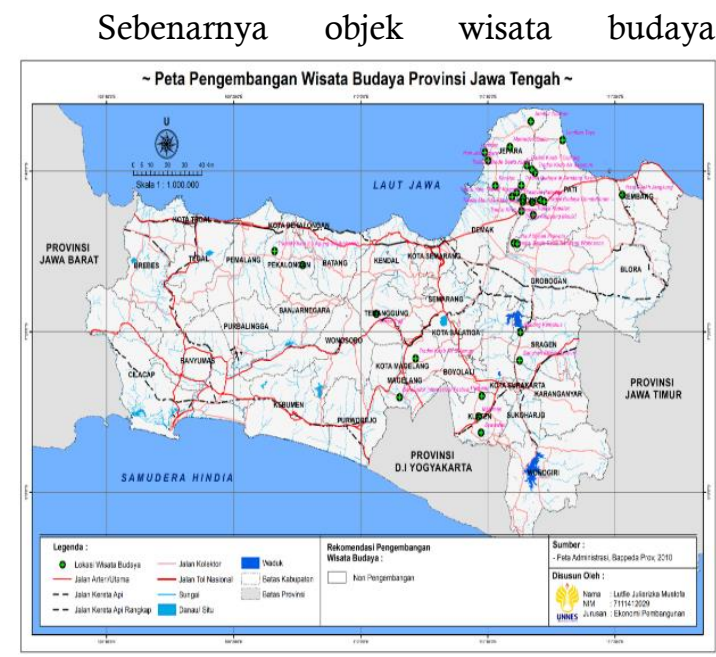

merupakan jenis wisata yang jarang dikelola. Kabupaten/kota di jawa Tengah hanya ada empat yang mengelola wisata budaya yaitu Klaten, Sragen, Kota Semarang, dan Surakarta.

\section{SIMPULAN}

Kabupaten/Kota yang mempunyai keunggulan dalam pariwisata: Sektor Pariwisata Provinsi Jawa Tengah: Kab. Banjarnegara, Kab. Semarang, Kota Magelang, Kab. Kebumen, Wisata Alam: Kab. Banjarnegara, Kab.
Banyumas, Kab. Klaten, Kab. Wonosobo, Wisata Buatan: Kab. Banjarnegara, Kab. Semarang, Kota Magelang, dan Kota Surakarta, Wisata Bahari: Kab. Brebes, Kab. Demak, Kab. Kebumen, Kab. Purworejo, Kab. Rembang, dan Kota Pekalongan, Wisata Religi: Kab. Jepara dan Kab. Semarang, Wisata Sejarah: tidak ada kabupaten/kota yang untuk jenis wisata sejarah, Wisata Kesehatan: Kab. Kebumen, Kab. Magelang, Kab. Sragen, dan Kab. Wonosobo, Wisata Budaya: sama seperti wisata sejarah tidak ada kabupaten/kota yang unggul dalam wisata budaya.

Pemetaan pengembangan pariwisata dan jenis pariwisatanya di Provinsi Jawa Tengah adalah sebagai berikut: Sektor Pariwisata Provinsi Jawa Tengah yang direkomendasikan adalah Kab. Banjarnegara, Kab. Semarang, Kota Magelang, Kab. Kebumen, Wisata Alam yang direkomendasikan adalah Kab. Banjarnegara, Kab. Banyumas, Kab. Klaten, Kab. Wonosobo, untuk jenis wisata buatan yang direkomendasikan adalah Kab. Banjarnegara, Kab. Semarang, Kota Magelang, dan Kota Surakarta, Wisata Bahari yang direkomendasikan adalah Kab. Brebes, Kab. Demak, Kab. Kebumen, Kab. Purworejo, Kab. Rembang, dan Kota Pekalongan, untuk jenis wisata religi yang direkomendasikan untuk dikembangkan adalah Kab. Jepara dan Kab. Semarang, untuk jenis wisata sejarah dan wisata budaya di Provinsi Jawa Tengah tidak ada yang direkomendasikan untuk dikembangkan tetapi tetap dikelola dengan baik karena sejarah dan budaya merupakan identitas atau ikon suatu daerah, sedangkan untuk wisata kesehatan yang direkomendasikan untuk dikembangkan adalah Kab. Kebumen, Kab. Magelang, Kab. Sragen, dan Kab. Wonosobo

\section{DAFTAR PUSTAKA}

arikunto, suharsimi. 2006. prosedur penelitian suatu pendekatan praktik. jakarta : rineka cipta

arsyad, lincolin. 2004. ekonomi pembangunan. yogyakarta. stie ykpn.

basuki, agus tri dan gayatri utari. 2009. penentuan sektor unggulan dalam pembangunan daerah. jurnal ekonomi dan studi pembangunan. 
dinas kebudayaan dan pariwisata provinsi jawa tengah. 2011-2015.

emilia dan imelia. 2006. modul ekonomi regional. jurusan ilmu ekonomi fakultas ekonomi universitas jambi

suseno,d.(2015).pengembangan daerah berdasarkan tipologi pertumbuhan ekonomi dan ketimpangan sektor di wilayah kedung sepur. jejak: jurnal ekonomi dan kebijakan

suwantoro, gamal. 2005. dasar-dasar pariwisata. yogyakarta. andi

kementerian pariwisata republik indonesia. 20112015.

kuncoro, mudrajad. 2004. otonomi dan pembangunan daerah. jakarta: erlangga

pendit, nyoman s. 2002. ilmu pariwisata sebuah pengantar perdana. jakarta paradnya paramita

sjafrizal. 2008. ekonomi regional, teori dan aplikasi. jakarta. niaga swadaya.

tarigan, robinson. 2005. ekonomi regional: teori dan aplikasi. jakarta: bumi

aksara.

sugiyono. 2010. metode penelitian kuantitatif, kualitatif, dan r\&d. bandung alfabeta.

undang-undang negara republik indonesia nomor 10 tahun 2009. tentang

kepariwisataan.

warpani, suwardjoko p. 2007. pariwisata dalam tata ruang wilayah. bandung.

penerbit itb.

yoeti, oka a. 1996. pengantar pariwisata. bandung. angkasa 